DOI https://doi.org/10.30525/978-9934-26-038-4-63

\title{
ПРОТИМІКРОБНА АКТИВНІСТЬ АНТИСЕПТИЧНИХ ЗАСОБІВ ЩОДО ПРОВІДНИХ ЗБУДНИКІВ ІНФЕКЦІЙНИХ УСКЛАДНЕНЬ У ПЕРІОПЕРАЦЙНОМУ ПЕРІОДІ
}

\author{
Назарчук О. А. \\ доктор медичних наук, \\ дочент кафедри мікробіологіі \\ Вінницький національний медичний університет імені М. I. Пирогова
}

Багнюк Н. А.

аспірант кафедри мікробіології

Вінницький національний медичний університет імені М. І. Пирогова

Бабіна Ю. М.

аспірант кафедри анестезіології, інтенсивної терапії та медицини невідкладних станів

Вінницький національний медичний університет імені М. I. Пирогова

Дудар А. О.

асистент кафедри мікробіології

Вінницький начіональний медичний університет імені М. І. Пирогова м. Вінниця, Украӥна

Вступ. Згідно даних Всесвітної Організації Охорони Здоров'я (ВООЗ), близько 40\% інфекційних захворювань, які реєструються в періопераційному періоді зумовлені умовнопатогенними мікроорганізмами [1, с. 27]. Однією із основних причин зростання їх активності серед числа інших збудників хвороб є неконтрольоване, часто безпідставне збільшення використання антибіотиків у медицині та ветеринарії. $[2$, с. 1], що в свою чергу призводить до формування резистентних до них штамів мікроорганізмів та послаблення імунної реактивності організму людини. Домінуючими у етіології нозокоміальної інфекції (НI) все ще залишаються S.aureus, P.aeruginosa, A.baumannii, Enterobacter spp., Enterococcus spp [1, c. 28].

В таких умовах актуальність раціонального вибору антисептиків, які володіють протимікробною активністю набуває все більшого значення [3]. Для профілактики та в складі лікування інфекційних ускладнень в періопераційному періоді в Україні найчастіше використовують 
антисеитичні препарати 0,02 \% декаметоксин, 0,05 \% хлоргексидину бігліюконат, $10 \%$ повідон-йод. Препарати затверджені Постановою Кабінету Міністрів України від 25 березня 2009 р. № 333. Серед арсеналу сучасних антисептиків відомий також полігексанід [4, с. 83].

Незважаючи на доведену високу протимікробну ефективність антисептичних препаратів, все частіше 3'являються повідомлення щодо зростання проблеми резистентності бактерій до антисептиків та дезінфікуючих засобів, які разом із консервантами визначаються новим терміном - «біоциди» [5, с. 3]. 3 огляду на вище зазначене, 3'ясування закономірностей формування та поширення стійкості збудників нозокоміальної інфекції до антисептиків і дезінфектантів має стати основою для підвищення ефективності антисептичних та дезінфекційних заходів в стаціонарах та важливою складовою частиною епіднагляду за НI [6, с. 1].

Мета - провести мікробіологічне дослідження протимікробної ефективності лікарських антисептичних засобів декаметоксину, хлоргексидину, полігексаніду на ізолятах виділених від хірургічних хворих в періопераціійному періоді.

Матеріали та методи. У дослідженні було використано 158 клінічних штамів умовно-патогенних мікроорганізмів. Структура досліджуваних збудників інфекційних ускладнень була представлена ізолятами S.aureus $(\mathrm{n}=48)$, P.aeruginosa $(\mathrm{n}=44)$, A.baumannii $(\mathrm{n}=33)$, Enterobacter spp. $(\mathrm{n}=20)$, Enterococcus spp. $(\mathrm{n}=13)$. В роботі досліджували протимікробні властивості антисептичних засобів на основі $0,02 \%$ та $0,1 \%$ декаметоксину, 0,05 \% хлоргексидину біглюконату, 0,1\% полігексаніду. Ідентифікацію мікроорганізмів виконували відповідно до загальноприйнятих методів за морфологічними, тинкторіальними, культуральними, біохімічними властивостями. В дослідження оцінювали протимікробну дію антисептиків, визначаючи їх мінімальні інгібуючу (бактеріостатичну) та бактерицидну концентрації (МІК та МБцК, відповідно) щодо ізолятів умовно-патогенних мікроорганізмів стандартним методом двократних серійних розведень [7].

Порівняльну характеристику клінічної ефективності досліджуваних антисептичних лікарських препаратів щодо клінічних штамів умовнопатогенних мікроорганізмів проводили 3 використанням кількісного показника - індексу активності антисептику (IAA), який вираховували відповідно до методики. [8].

Результати. В результаті дослідження було встановлено достовірні переваги бактерицидних властивостей декаметоксину в порівнянні 3 хлоргексидином щодо клінічних штамів золотистого стафілококу

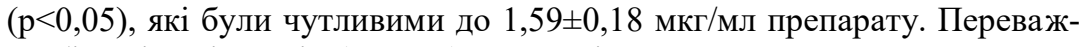
на більшість ізолятів $(85,4$ \%) синьогнійної палички проявляли чутли- 


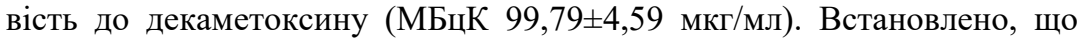
бактерицидні концентрації декаметоксину щодо Enterococcus spp. були меншими, ніж в хлоргексидину в 10,5 разів. Бактерицидну дію декаметоксину на клінічні A.baumannii вищначили в присутності МБцК, яка була в 3.1 рази меншою від таких у полігексаніду та у 2 рази меншою від хлоргексидину. Бактерицидні властивості хлоргексидину щодо A.baumannii визначали при застосуванні вищої в 2,4 рази концентрації антисептика. Хлоргексидин проявляв бактерицидну дію на Enterobacter

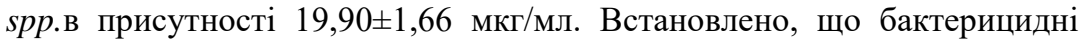
концентрації хлоргексидину щодо S.aureus були більшими у 3,5 рази, ніж в декаметоксину. Полігексанід проявляв подібні бактерицидні властивості щодо ентеробактерів та стафілококів (18,48 $\pm 1,75$ мкг/мл). Доведено, що клінічні штами A.baumannii володіли подібною високою чутливістю до полігексаніду, як Enterobacter spp. $(161,93 \pm 16,95)$ ( $>00,05)$. Полігексанід проявляв бактерицидні антипсевдомонадні властивості в присутності 213,12 $\pm 17,62$ мкг/мл.

В результаті аналізу показників IAA встановлено високу антимікробну ефективність декаметоксину щодо грампозитивних та грамнегативних умовно-патогенних мікроорганізмів. Доведено суттєві переваги антимікробної ефективності даного антисептика щодо S.aureus в порівнянні 3 0,05\% хлоргексидином та $0,1 \%$ полігексанідом відповідно в 2,5 та 10,5 рази $(\mathrm{p}<0,05)$. За протимікробною ефективністю щодо ентерококів $0,1 \%$ полігексанід та $0,05 \%$ хлоргексидин переважали за IAA 0,02 \% декаметоксин (в 6,4 та 3,8 раза, відповідно; p $<0,001$ ). Встановлено переваги протимікробної ефективності полігексаніду в концентраціях готової лікарської форми щодо клінічних штамів P.aeruginosa $(\mathrm{p}<0,001)$.

Висновки. Поверхнево-активні антисептики декаметоксин, хлоргексидин, полігексанід володіють високими бактерицидними властивостями щодо клінічних штамів грампозитивних та грамнегативних умовно-патогенних мікроорганізмів. Встановлені достовірні високі бактерицидні властивості декаметоксину щодо збудників хірургічних інфекційних ускладнень. Це доводить доцільність застосування даних препаратів з метою профілактики та в складі комплексного лікування інфекційних ускладнень у періопераційному періоді.

\section{Література:}

1. World Health Organization. Global Guidelines for the Prevention of Surgical Site Infection [Internet]. Geneva, Switzerland: WHO. 2016. San Francisco: Matthew Holt. 2003 Oct [cited 2018_Aug 30]. Available from: http://apps.who.int/iris/bitstream/handle/10665/250680/9789241549882eng.pdf;jsessionid=1F8A9546C46F1803027E22A3F82DBEE4? sequence=1 
2. Палій Г.К., Павлюк С.В., Палій Д.В., Назарчук О.А., Дудар А.О. Обгрунтування застосування антисептичних препаратів в системі профілактичних і лікувальних заходів (огляд літератури). Буковинський медичний вісник. 2018. № 22(4). С. 51-56.

3. Десятерик В.І. Фрагмент Всеукраїнського дослідження чутливості мікрофлори до антибактеріальних препаратів хворих з інтраабдомінальною хірургічною інфекцією / В.І. Десятерик, О.В. Котов, П.Г. Теліга, T.І. Савченко // Клінічна хірургія. - 2011. - № 6. - С. 38-40.

4. Палій Г.К.; Ковальчук В.П.; Фоміна Н.С. Характеристика сучасного арсеналу дезінфекційних засобів та проблеми дезінфектологiï. Biomedical and biosocial anthropology. 2014. № 22. С. 82-85.

5. Салманов А.Г., Марієвський В.Ф., Хобзей М.К. Резистентність бактерій до антисептиків та дезінфікуючих засобів. Украӥнський медичний часопис. 2010. № 6. С. 51-56.

6. Гудкова Е.И., et al. Формирование устойчивости к антисептикам и дезинфектантам возбудителей внутрибольничных инфекций и ее микробиологический мониторинг. Бел. мед. Журнал. 2003. № 3. С. 57-60.

7. Про затвердження методичних вказівок «Визначення чутливості мікроорганізмів до антибактеріальних препаратів» : наказ № 167 від 05.04.2007 p. [Електронний ресурс]. Міністерство охорони здоров’я України. Нормативно-директивні документи МОЗ України. Доступно: http://mozdocs.kiev.ua/view.php?id=6958

8. Красильников А.П. Справочник по антисептике. Минск: Вышейшая школа. 1995. - С. 470.

DOI https://doi.org/10.30525/978-9934-26-038-4-64

\section{СТАН АТМОСФЕРНОГО ПОВІТРЯ ЕКОЛОГІЧНО НЕБЕЗПЕЧНОГО РЕГІОНУ}

\section{Павленко О. I.}

кандидат медичних наук, старший дослідник, завідувач лабораторії промислових аерозолів

ДУ «Український науково-дослідний інститут промислової медицини» м. Кривий Ріг, Дніпропетровська область, Украӥна

Низький рівень здоров'я населення України, спричинений несприятливою екологічною та соціально-економічною ситуацією, нездоровим харчуванням кризою медичної галузі, зумовлює нагальну потребу ком- 